\title{
The evolution of energy efficiency impact on housing prices. An analysis for Metropolitan Barcelona
}

\section{La evolución del impacto de la eficiencia energética en los precios residenciales. Un análisis para la Barcelona Metropolitana}

Carlos Marmolejo-Duarte (Main and Correspondence Author) Departamento de Tecnología en la Arquitectura, Centro de Política de Suelo y Valoraciones, Escuela Técnica Superior de Arquitectura de Barcelona, Universidad Politécnica de Cataluña

Diagonal, 649,4a, Arq Legal, 08028, Barcelona (Spain) https://orcid.org/0000-0001-7051-7337

carlos.marmolejo@upc.edu

\section{Ai Chen}

Departamento de Tecnología en la Arquitectura, Centro de Política de Suelo y Valoraciones, Escuela Técnica Superior de Arquitectura de Barcelona, Universidad Politécnica de Cataluña

Diagonal, 649,4a, Arq Legal, 08028, Barcelona (Spain) https://orcid.org/0000-0002-8912-0660

ai.chen@upc.edu

Manuscript Code: 1149

Date of Acceptance/Reception: 29.01.2019/16.07.2018

DOI: 10.7764/RDLC.18.1.156

\begin{abstract}
The Energy Performance of Buildings Directive has it made mandatory to include an energy performance certificate (EPC) on real estate advertisements so as to promote efficient properties. Previous research has found a positive correlation between residential prices and EPC's energy ranks; nonetheless, the analysis of the evolution of such impact for the same market is still pending. This paper tries to shed light on this issue by analyzing the evolution of prices of the second largest urban agglomeration in Spain. In doing so, a pooled hedonic model is carried out departing from selling listing prices of apartments and a set of locative control variables. Results suggest that in a short period the energy premium for multifamily houses has positively evolved. As a result, a sharped market differentiation arises between inefficient and energy saving dwellings. Such findings have significant implications for the construction and real estate industry, since higher selling prices may compensate for higher building costs coming from energy efficient technologies.
\end{abstract}

Keywords: Hedonic price models, real estate valuation, energy efficiency, energy performance certificates, Barcelona.

Resumen

La Directiva de la Eficiencia Energética en la Edificación obliga la inclusión de la etiqueta derivada de un certificado de eficiencia energética (CEE) en la publicidad inmobiliaria con el objetivo de promover edificios energéticamente eficientes. En la literatura está bien establecida la correlación positiva entre los precios residenciales y las clases energéticas de los CEE; sin embargo, la evolución de dicha correlación en dicho mercado es un tema pendiente. Este trabajo intenta avanzar en ese sentido a partir del análisis de la evolución de los precios en la segunda aglomeración urbana en España. Para ello, se utiliza un modelo de precios hedónicos con datos provenientes de precios de oferta de apartamentos y de un conjunto de variables locativas de control. Los resultados sugieren que en un periodo corto de tiempo el sobreprecio energético de las viviendas plurifamiliares ha tenido una evolución positiva, emergiendo una diferenciación importante entre las viviendas ineficientes y aquéllas que ahorran energía. Estos hallazgos, tienen implicaciones importantes para el sector inmobiliario y de la construcción en tanto cuanto un mayor precio de venta podría compensar los mayores costes de construcción derivados de la edificación energéticamente eficiente.

In order to foster energy-efficient buildings, the European Commission issued the Energy Performance of Buildings Directive (EPBD 2002/91/EC), recast in 2010/31/UE. The main hypothesis of such communitarian policy is that building users (i.e. buyers and tenants) should elicit in preferential conditions efficient buildings when they are informed on energy consumption and $\mathrm{CO}_{2}$ emissions. So, individuals may be willing to pay more for taking advantage of energy savings and environmental preservation. In doing so, the Directive obligates real estate owners willing to sell or lease properties to get an Energy Performance Certificate (EPC) and include the derived energy rank in the advertising of the property. In sum, by breaking down energy information asymmetries, the EU tries to promote the construction of efficient buildings and the energy retrofit of existing ones (Encinas et al., 2018).

In Spain the transposition of the Directive has been implemented by means of different legal instruments, being the RD $235 / 2013$ the most import one. According to this legal text, as from $1^{\text {st }}$ of June 2013 , almost all properties to be let (to 
a new tenant) or sell must exhibit the EPC rank when advertised (Marmolejo \& Bravi, 2017). The previously published research, reviewed in the next section, has found that EPC ranks are positively correlated with housing prices both in Spain and other EU member states.

\section{Description of the problem}

The impact of EPC ranking in the Spanish residential market is sharply smaller than in other northern European countries. Behind such divergence, authors have argued differences on climatic conditions, income, property prices as well as diverging concerns on environment conservation. Whether such impact remains low along the time is still a pending question. This paper tries to shed light on it, by means of two objectives:

1) Study the evolution of EPC impacts on residential prices along the time

2) Study if such evolution is linear among energy ranks.

In doing so, a large dataset has been gathered for the Metropolitan Area of Barcelona, the second largest urban agglomeration in Spain and the sixth in Europe. Selling listing prices have been acquired from one of the largest real estate websites in Spain providing extensive coverture of the residential market. The study is constrained to apartments since this is the dominant typology of dwellings in Mediterranean cities. In order to get unbiased results, considerable efforts have been made in order to incorporate control variables related to 1) territorial, 2) urban, 3) environmental and 4) socioeconomic aspects of the micro-location of each of the apartments. Such information has been analyzed by a set of hedonic models, in order to identify the impact of energy ranking on selling listing prices and its evolution.

The remainder of the paper is organized as follows: firstly, a review of the previous research on energy efficiency and real estate prices both in Europe and Spain is offered; secondly, the case study, data, and methodology is explained; as a third part the results are discussed, and in the concluding section, an overview of the research and its implications for the building industry are included.

Brief literature review

In the literature, the positive influence of energy efficiency and more generally sustainable attributes as measured by means of environmental certifications schemes and their respective "green labels" is well established. In particular, the evidence regarding such influence coming from the EPC scheme is quite more recent concerning previously settled programs such as LEED, BREEAM or Energy Star.

The pioneering study by Brounen \& Kok (2011) analyzed the impact of EPC labels on residential prices in The Netherlands; although, the data used come from the period in which the purchasing part could exempt the selling part of delivering an EPC. The results of this study found a positive correlation between the best-ranked dwellings and sale prices in real estate transactions. These authors assume that energy ranks are a categorical measure of the efficiency of housing. Therefore, considering the intermediate rank "D", as a basis for comparison, they found that the marginal price ranged from $10 \%$ for the " $\mathrm{A}$ " class, to $-5 \%$ for the "G" class. That is, above the reference market premiums are formed, while below market penalties appear. The study by Hyland et al. (2013) conducted in a set of Irish cities was the first to simultaneously compare the impact of EPC in the rental and sale markets. In doing so, these authors departed from listing prices of both markets, finding that the impact of the energy ranking is greater in the market of sale than in the rental one. For example, a home for sale ranked as "A" (in relation to "D") has a market premium of 9.3\%, and only $1.8 \%$ if it is transacted in the rental market, all the remaining attributes being the same. Likewise, the market penalty for a home ranked as "F" or "G" (in relation to "D") is significantly higher (-10.60\%) than the penalty received in the rental market (-3.20\%). The larger impact of green labels on sale prices, in relation to rental prices, is a regularity that already had been reported by previous work based on other certification schemes (Marmolejo, 2016).

In the work of Bio intelligence Service (2013) (see Table.1), the impact of EPC is higher in selling prices than in housing rents. From this study, it should be noted that EPCs appear to have a sharper impact on hinterlands (e.g. Belgium and Ireland, with Austria as an exception) than in capital cities. According to its authors, such differential impact can be explained by the fact that savings in energy bills regarding the base price of housing, are more important in rural areas where the housing price is lower. Also, not always a higher energy rating implies a market premium, since in the rental market of Oxford there is apparently a penalty for the best-ranked dwellings (-4\% per EPC rank). The authors of this work have recognized the enormous deficiencies of their analysis, since the older and better located, high-priced stately dwellings have, in turn, a low energy rank in that city. In general, the very poor control of urban characteristics (i.e. accessibility, quality of urbanization and social hierarchy) driving residential values is a deficiency of such work and can 
bias the coefficients of its models. In Belfast Davis et al. (2015) have also found that efficient homes command a higher price, according to their semi-log hedonic regression, the sale price increases $0.4 \%$ for each of the EPC ranks. Nonetheless, this impact is not the same for different age (i.e. styles) and typologies of homes. The same conclusion has been extracted by Marmolejo \& Chen (2019a) in their analysis of listing prices in Barcelona. Their analysis suggests that the impact of EPC rankings is null in the case of recently completed state-of-the-art apartments. On the contrary, in the case of postwar apartments targeted to low-income population boasting the poorest quality the impact is large. According to such authors in this latter case, EPC rankings proxy for quality of apartments in absence of amenities, playing, in that sense, an incorrect role in price differentiation. In another study Marmolejo \& Chen (2019b) they have found that in some housing markets EPC rankings appear as inversely correlated with prices, proably due to lack of supervision on the advertisement of EPC labels

In Sweden, Cerin et al. (2014) have carried out a peculiar study in which the sale price of the dwellings has been correlated directly with the energy consumption contained in the EPC label. The coefficient of energy consumption in their hedonic model appears with a contradictory sign ( $B x=0.06, p=0.000)$, where $x$ is the log of consumption in $\mathrm{kWh} /$ year $/ \mathrm{m}^{2}$ and $Y$ the log of the price per $\mathrm{m}^{2}$ ): the higher the consumption in $\mathrm{kWh} /$ year $/ \mathrm{m}^{2}$, the larger the housing price, everything else equal. It is highly probable that simple energy ranks are clearer than more precise technical units.

Table 1. EPC impacts on residential prices in a selected set of European cities. Source: Own elaboration based on Bio Intelligence Service (2013).

\begin{tabular}{|c|c|c|c|c|}
\hline \multirow[b]{2}{*}{ Case study } & \multicolumn{2}{|c|}{ Impact of EPC ranks on prices } & \multirow[b]{2}{*}{ Used prices } & \multirow[b]{2}{*}{ Data source } \\
\hline & Sell (\%) & Lease (\%) & & \\
\hline Wien & Between 10 and 11 & Between 5 and 6 & Asking & Web portal \\
\hline Lower Austria & Between 5 and 6 & 4.40 & Asking & Web portal \\
\hline $\begin{array}{l}\text { Brussels } \\
\text { (Flanders) }\end{array}$ & 4.30 & 3.20 & Asking & Web portal \\
\hline Brussels (Capital) & 2.90 & 2.60 & Asking & Web portal \\
\hline $\begin{array}{l}\text { Brussels } \\
\text { (Wallonia) }\end{array}$ & 5.40 & 1.50 & Asking & Web portal \\
\hline Lille & 3.20 & nd & Transaction & Notary \\
\hline Marseille & 4.30 & nd & Transaction & Notary \\
\hline Irish cities & 1.70 & 1.40 & Asking & Web portal \\
\hline Irish country side & 3.80 & 1.40 & Asking & Web portal \\
\hline UK (Oxford South) & 0.40 & -4 & Asking & Web portal \\
\hline
\end{tabular}

So far, there is a significant divergence in the impact of EPC rankings on residential values throughout Europe, explained by the essential differences regarding income, energy costs, construction, climate, legal requirements, and environmental concerns. Moreover, Garcia-Hooghuis and Neila (2013) have pointed out that the way in how the EPBD has been transposed across the Member States has resulted in different calculation methods, making cross-border comparisons difficult. However, the positive impact on prices reviewed before contrast with the outcomes of opinionbased research. Murphy [2014] conducted a survey in the Netherlands in order to identify the impact of EPC information on price negotiation in the context of home purchasing. Her results suggest that "a higher EPC fails to have a direct influence during negotiation and decision making" (p. 666). In the same line, Parkinson et al. (2013) have found, surveying commercial office occupants in the UK, no correlation between EPC ratings and rental values, their findings suggest that facilities' aesthetic is the main driver of rents. Compatible evidence can be found in the study of Pascuas et al. (2017) based on surveys applied to real estate agents in eight countries. According to their results, EPC ratings exert a negligible impact on housing prices, this conclusion is especially valid in the case of Spain where only $15 \%$ of the surveyed agents confirmed the existence of a premium for efficient flats. Departing from such contradictory evidence, that is: on the one hand a positive market premium for efficient properties suggested by hedonic models; and on the other hand, no strong evidence on EPC impact on prices and rents coming from demand and agents' surveys, Olaussen et al. (2017) have carried out an interesting quasi-natural experiment in order to identify whether omitted variables in model specifications can lead to spurious results. Their study, based on the Oslo's residential market, consists of analyzing the price of homes sold before and after July 2010 when it became mandatory to include in advertisings the EPC labels, so as to identify whether such labels did actually produce a price increase in the case of efficient homes. In doing so, they assign the EPC class to each home in the pre-2010 sample according to the class the same home had in the post-2010 sample. Their hedonic results show similar market premiums and penalties on EPC ratings for the pre and post 2010 samples, allowing them to conclude that "price premium of the energy labels clearly captures something else than an effect to the labels themselves" (p. 251). Nonetheless, such authors warn that even when EPC rating does not matter in Norway, they could matter in other countries, possibly where trust and honesty on building industry are 
lacking. All in all, it is necessary to carefully incorporate control variables, as it is done in this paper, in order to reduce the risk of omitting relevant attributes.

In Spain, there are two pioneering works in the study of the hedonic agenda of the EPC. The work of De Ayala et al. (2016) is based on "opinion values" declared by a sample of respondents from 5 cities (Madrid, Bilbao, Seville, Vitoria, and Málaga) with an own calculation of the energy EPC rank. It has found that dwellings with " $A$ ", " $B$ " or " $C$ " energy ranks have a value, in the opinion of their owners, higher by $9.8 \%$ than those rated as " $D$ ", " $E$ ", " $F$ " or " $G$ ". Marmolejo (2016) uses listing prices for a sample of dwellings in Barcelona and found an over price of 5.11\% for the G->A improvement, or $9.62 \%$ if it is accepted that people perceive the ranking scale to be nominal. All in all, the impact of EPC ranks on prices is significantly smaller in Barcelona in relation to other European cities. In Turin, the conclusions laid by the study of Fregonara \& Rolando (2016) point out a null impact of EPC rankings when other architectonic attributes are taken into consideration. This evidence stresses the necessity to furtherly explore the hedonic agenda of EPC rankings in Southern Europe. Especially because, according to Marmolejo (2016), the tiny market premium found in Barcelona cannot compensate the more substantial construction costs associated to higher energy efficiency standards, which constitutes a negative signal to construction companies and real estate developers willing to promote efficient buildings. Whether such incidence is stable along the time is still an open question tried to be solved by this paper as it is next discussed.

\section{Methodology}

The study area is the Metropolitan Region of Barcelona, which is officially comprised of 164 municipalities. In Spain transaction prices are unknown since information coming from the Property Register is only provided in an aggregated manner, containing no information about structural attributes of properties but the built area; furthermore, such information comes from self-declarations in public deeds, so it may diverge from actual prices. For these reasons in this paper listing selling prices are analyzed. Listing prices and characteristics of apartments and the respective buildings have been acquired from Habitaclia, one of the leading real estate websites in Catalonia. The two dates of datasets retrieved are: the $1^{\text {st }}$ November 2014 and the $1^{\text {st }}$ April 2016, both of them are posterior to the RD 235/2013 and this period comprises the end of one of the largest real estate crises in the history of Spain. Architectonic features include: floor area, number of rooms, number of baths, living room area, terrace/balcony area, story where the flat is placed, heat/air conditioning systems, information regarding renewal, EPC rank, penthouse position, number of levels (in the case of duplex/triplex dwellings), etc. as well as condominium services such as lift, swimming pool, private greenery, age, etc.

In order to make a comprehensive control of other locative attributes influencing housing prices, a significant effort has been made gathering the following information:

- Regarding socioeconomic, environmental and accessibility data, information from the 2001 Housing and Population Census (Unfortunately, it was not possible to use 2011 data census since, due to the crisis in Spain, such census is based on a restricted sample survey, which is not statistically reliable at census tract level) has been retrieved at census tract level with the following detail: a) data regarding the social status of the neighborhood (e.g. education attainment, job position of resident employed population in the context or their firms, percentage of residential buildings with doorman service, etc.); information regarding the accessibility (e.g. declared time to get the workplace); data regarding the environmental quality of the neighborhood (e.g. greenery perception); information regarding the available services (health-care, education, sociocultural, retail, office-based services, etc.).

- $\quad$ Regarding the built-up density and area allocated from a selection of land use, information of the latest 2013 cadastral database has been retrieved at census tract level.

- $\quad$ Regarding the presence of transport systems and territorial externalities, an own digitalization process has been implemented so as to identify: train stations (subway, metropolitan trains, tram and other railway transports such as funiculars), highway ramps, the coastal line and the limits of natural parks (including those of submarine nature due to the externalities that might emerge from them).

- Regarding the centrality of zones, information coming from the 2001 metropolitan survey at transport zone level has been retrieved.

Using this latter information, a synthetic indicator of centrality has been built as follows:

1) Firstly, some intermediate-variables were computed. Some of such intermediate-variables are time-density (Marmolejo \& Cerda, 2012; Marmolejo et al., 2016); diversity of activities; socioeconomic diversity of people that perform activities in a given zone; distance traveled by people performing activities in a given zone, etc. All the variables were computed for different days in the week and 5 time-strips. 
2) Secondly, intermediate-variables were encapsulated in a synthetic indicator of centrality using DP2 methodology (Pena, 1977, Zarzosa, 2009).

In Marmolejo \& Cerda (2017) all the details concerning the construction of the synthetic indicator of centrality are provided and theorized in the more general framework of time-geography.

Since the geographical entities of data used are divergent: points for studied dwellings, census tract for census and cadastral data and transport zones for mobility information, it was used a geographic information system. Using a buffer of $300 \mathrm{~m}$ radius (In addition, it was used a buffer of $600 \mathrm{~m}$ radius; nevertheless, the model built with such data exhibits a lower fit in comparison to that presented in this paper) around each of the apartments and geospatial queries, all the information was transferred to each of the apartments contained in the dataset.

The complete dataset comprises 35,116 apartments for the year 2014 and 49,424 for the year 2016; the larger amount of cases in this latter year is a signal of the recovery of the real estate market after eight years of economic downturn. Nonetheless, despite the abovementioned obligation to include the energy ranking the advertisement, a large quantity of cases does not contain such information. In general we have found that apartments disclosing the EPC ranks are slightly better in terms of quality than those without such information. Nonetheless, such difference does not produce a significant bias on the estimation of the regression coefficients according to the 2-step Heckman procedure. For the year 2014-sample the compliance rate is $12 \%$ and for the year 2016 is $15 \%$. As a result, the sample sizes are reduced. In order to eliminate outliers, the following procedure has been applied to each separated annual sample:

- $\quad$ Firstly, all flats with unitary prices beyond +/-1 standard deviation from the average unitary price were discarded.

- Next, a family of regression models was calculated, using the model with the best fit the Mahalanobis Distance was computed. According to Marmolejo \& González (2009), this procedure allows for the elimination of outliers in the $n$-variables used in the regression analysis.

- $\quad$ Finally, it was detected the Mahalanobis Distance breaking point (i.e. the value where the slope increases abruptly) by using a sedimentation analysis.

The final depurated sample comprises 3,246 cases for the year 2014, and 5,139 cases for the year 2016. In order to guarantee a similar size for both of the year-samples, a random selection process has been implemented in the latter annual sample. As a result, the pooled sample is made of 6,492 cases. Table 1 exhibits the descriptive statistics of the main variables organized in conceptual dimensions.

From such data, it is clear that for the year 2014 the "average apartment" exhibits: a price of 162,851 Euros, an area of $84 \mathrm{~m}^{2}, 1.3$ bathrooms, 2.9 bedrooms, and its average height-location is 2.1 stories with an average terrace area of 12 $\mathrm{m}^{2}$. Regarding the condominium shared spaces, it is important to note that $4 \%$ of apartments have swimming pools, $9 \%$ gardens and $46 \%$ lift service. The conditioning systems are also presented: $31 \%$ of the apartments have air conditioner while $43 \%$ central heating system.

In terms of energy efficiency, the average ordinal EPC rank $(G=1, A=7)$ is 2.7 . While class $A$ comprises only $2 \%$ of the sample, Class B is not present after depurating the data, being Class $E$ the most abundant (49\%) followed by class $G$ $21 \%$. Regarding the average location, $93 \%$ are located in municipalities with access to a metropolitan highway, and $50 \%$ near to a railway station (including subway, tram, and funicular). Both the population and employment densities proxies for centrality and service presence, as it can be seen the minimum value for such attributes is 11 residents $/ \mathrm{km}^{2}$ and 5 jobs $/ \mathrm{km}^{2}$ reaching 144,421 residents $/ \mathrm{km}^{2}$ and $56,454 \mathrm{jobs} / \mathrm{km}^{2}$ respectively in the most central/serviced zones. $1.2 \%$ of the apartments are located within 200 meters from the seashore which proxies for environmental quality.

Regarding the socioeconomic level of the zones where the apartments are located, $7 \%$ of the neighboring housing has doorman service as an average, $11 \%$ of neighbors hold a university degree and $8 \%$ work in managerial positions. Since these variables are closely correlated As a matter of fact, most of the variables in the dataset are correlated. Nonetheless, the models do not exhibit multicollinearity problems, since this issue has been controlled keeping the VIF well below 2.5 (except for the case of the area and the squared area since it allows to model a diminishing marginal function for this attribute), a factor analysis has been used including the job positions and education level. As a result, there are two principal components: PC1-High Income proxies for high-income job positions/high education level, the larger its value, the higher the proportion of neighbors in managerial, professional and specialized technical job positions as well as the higher the education level. PC2-Med Income proxies for medium income level, incorporating 
clerks, service vendors or qualified manufacturing positions. Since such synthetic indicators are produced by means a factor analysis, they are completely uncorrelated.

Table 2. Descriptive statistics for the 2014 \& 2016 depurated sample and selected variables. Source: Own elaboration.

\begin{tabular}{|c|c|c|c|c|c|c|c|c|c|}
\hline & \multirow[b]{2}{*}{$\mathrm{N} \times 2$} & \multicolumn{4}{|c|}{2014 Sample } & \multicolumn{4}{|c|}{2016 Sample } \\
\hline & & Min & Max & Mean & $\begin{array}{c}\text { Std. } \\
\text { Deviation }\end{array}$ & Min & Max & Mean & $\begin{array}{c}\text { Std. } \\
\text { Deviation }\end{array}$ \\
\hline \multicolumn{10}{|c|}{ Structural architectonic characteristics of apartments } \\
\hline Total price (Euros) & 3,246 & 34,000 & 715,000 & 162,851 & 88,957 & 48,000 & 830,000 & 229,507 & 153,812 \\
\hline Unitary price (Euro/m²) & 3,246 & 845 & 3,542 & 1,914 & 661 & 602 & 10,172 & 2,592 & 1,295 \\
\hline Area $\left(\mathrm{m}^{2}\right)$ & 3,246 & 25 & 234 & 84 & 28 & 20 & 380 & 87 & 32 \\
\hline Number of bathrooms & 3,246 & - & 4 & 1.3 & 1 & - & 4 & 1.4 & 1 \\
\hline Number of bedrooms & 3,246 & - & 15 & 2.9 & 1 & - & 10 & 2.9 & 1 \\
\hline $\begin{array}{l}\text { Ration } \\
\text { bathroom/bedroom }\end{array}$ & 3,246 & - & 2 & 0.5 & 0 & - & 2 & 0.5 & 0 \\
\hline Level of the apartment & 3,246 & - & 13 & 2.1 & 2 & - & 19 & 2.2 & 2 \\
\hline Terrace $\left(m^{2}\right)$ & 3,246 & - & 256 & 9.5 & 14 & - & 240 & 9.5 & 21 \\
\hline Living room area $\left(\mathrm{m}^{2}\right)$ & 3,246 & - & 90 & 12 & 10 & - & 102 & 12 & 12 \\
\hline Large terrace (Dummy) & 3,246 & 0 & 1 & $7 \%$ & & 0 & 1 & $13 \%$ & \\
\hline Air conditioner (Dummy) & 3,246 & 0 & 1 & $31 \%$ & & 0 & 1 & $48 \%$ & \\
\hline Central heating (Dummy) & 3,246 & 0 & 1 & $43 \%$ & & 0 & 1 & $68 \%$ & \\
\hline $\begin{array}{l}\text { Retrofited apartment } \\
\text { (Dummy) }\end{array}$ & 3,246 & 0 & 1 & $11 \%$ & & 0 & 1 & $19 \%$ & \\
\hline \multicolumn{10}{|c|}{ Energy performance of apartments } \\
\hline Energy class (ordinal) & 3,246 & 1 & 7 & 2.70 & & 1 & 7 & 2.84 & \\
\hline Energy class G (Dummy) & 3,246 & 0 & 1 & $21 \%$ & & 0 & 1 & $19 \%$ & \\
\hline Energy class F (Dummy) & 3,246 & 0 & 1 & $14 \%$ & & 0 & 1 & $13 \%$ & \\
\hline Energy class E (Dummy) & 3,246 & 0 & 1 & $49 \%$ & & 0 & 1 & $50 \%$ & \\
\hline Energy class D (Dummy) & 3,246 & 0 & 1 & $10 \%$ & & 0 & 1 & $11 \%$ & \\
\hline Energy class C (Dummy) & 3,246 & 0 & 1 & $4 \%$ & & 0 & 1 & $3 \%$ & \\
\hline Energy class B (Dummy) & 3,246 & na & na & na & na & 0 & 1 & $1 \%$ & \\
\hline Energy class A (Dummy) & 3,246 & 0 & 1 & $2 \%$ & & 0 & 1 & $3 \%$ & \\
\hline \multicolumn{10}{|c|}{ Architectonic characteristics of the buildings } \\
\hline Swiming pool (Dummy) & 3,246 & 0 & 1 & $4 \%$ & & 0 & 1 & $11 \%$ & \\
\hline Garden (Dummy) & 3,246 & 0 & 1 & $9 \%$ & & 0 & 1 & $16 \%$ & \\
\hline Lift (Dummy) & 3,246 & 0 & 1 & $46 \%$ & & 0 & 1 & $67 \%$ & \\
\hline Building age & 3,246 & 0 & 104 & 45 & 18 & 0 & 326 & 46 & 25 \\
\hline \multicolumn{10}{|c|}{ Locative attributes (transport, centrality and amenities) } \\
\hline $\begin{array}{l}\text { Commuting time } \\
\text { (minutes) }\end{array}$ & 3,246 & 12.9 & 41.0 & 24.0 & 4.5 & 12.9 & 41.4 & 24.6 & 3.9 \\
\hline Highway ramp (Dummy) & 3,246 & 0 & 1 & $93 \%$ & $26 \%$ & 0 & 1 & $94 \%$ & $23 \%$ \\
\hline $\begin{array}{l}<800 \text { m from railway } \\
\text { station (Dummy) }\end{array}$ & 3,246 & 0 & 1 & $50 \%$ & $50 \%$ & 0 & 1 & $56 \%$ & $50 \%$ \\
\hline $\begin{array}{l}\text { Pop. density } \\
\text { (residents } / \mathrm{km}^{2} \text { ) }\end{array}$ & 3,246 & 11 & 144,421 & 21,935 & 22,700 & 16 & 152,596 & 24,262 & 23,273 \\
\hline $\begin{array}{l}\text { Employment density } \\
\text { (jobs } / \mathrm{km}^{2} \text { ) }\end{array}$ & 3,246 & 5 & 56,454 & 9,511 & 9,738 & 7 & 73,563 & 10,548 & 10,078 \\
\hline Centrality index & 3,246 & 3.5 & 20.5 & 11.4 & 2.4 & 4.7 & 20.5 & 12.0 & 2.7 \\
\hline $\begin{array}{l}\text { Average gross area floor } \\
\text { ratio }\left(\mathrm{m}^{2} / \mathrm{m}^{2}\right)\end{array}$ & 3,246 & 0.2 & 6.0 & 2.0 & 1.3 & 0.2 & 6.0 & 2.3 & 1.6 \\
\hline $\begin{array}{l}<200 m \text { from sea shore } \\
\text { (Dummy) }\end{array}$ & 3,246 & 0 & 1 & $1.2 \%$ & & 0 & 1 & $3.9 \%$ & \\
\hline \multicolumn{10}{|l|}{ Socio-economic attributes } \\
\hline Doorman (\%) & 3,246 & $0 \%$ & $72 \%$ & $7 \%$ & $10 \%$ & $0 \%$ & $94 \%$ & $10 \%$ & $14 \%$ \\
\hline $\begin{array}{l}\text { People with university } \\
\text { degree (\%) }\end{array}$ & 3,246 & $1 \%$ & $44 \%$ & $11 \%$ & $8 \%$ & $1 \%$ & $47 \%$ & $14 \%$ & $10 \%$ \\
\hline Managers (\%) & 3,246 & $1 \%$ & $34 \%$ & $8 \%$ & $4 \%$ & $1 \%$ & $32 \%$ & $10 \%$ & $5 \%$ \\
\hline Professionals (\%) & 3,246 & $1 \%$ & $45 \%$ & $11 \%$ & $8 \%$ & $1 \%$ & $44 \%$ & $14 \%$ & $10 \%$ \\
\hline Technicians (\%) & 3,246 & $3 \%$ & $25 \%$ & $13 \%$ & $4 \%$ & $2 \%$ & $25 \%$ & $14 \%$ & $4 \%$ \\
\hline Clerks (\%) & 3,246 & $3 \%$ & $21 \%$ & $11 \%$ & $3 \%$ & $3 \%$ & $21 \%$ & $11 \%$ & $3 \%$ \\
\hline Service vendors (\%) & 3,246 & $3 \%$ & $29 \%$ & $15 \%$ & $3 \%$ & $5 \%$ & $33 \%$ & $15 \%$ & $4 \%$ \\
\hline Agriculture (\%) & 3,246 & $0 \%$ & $8 \%$ & $1 \%$ & $1 \%$ & $0 \%$ & $10 \%$ & $1 \%$ & $1 \%$ \\
\hline $\begin{array}{l}\text { Craft \& qualified } \\
\text { manufacture (\%) }\end{array}$ & 3,246 & $2 \%$ & $39 \%$ & $17 \%$ & $6 \%$ & $1 \%$ & $37 \%$ & $15 \%$ & $7 \%$ \\
\hline Manufacturing (\%) & 3,246 & $1 \%$ & $40 \%$ & $13 \%$ & $6 \%$ & $1 \%$ & $36 \%$ & $11 \%$ & $6 \%$ \\
\hline Non qualified jobs (\%) & 3,246 & $2 \%$ & $32 \%$ & $10 \%$ & $4 \%$ & $1 \%$ & $32 \%$ & $9 \%$ & $5 \%$ \\
\hline PC1 High income (factor & 3,246 & - & 3.86 & - & 0.81 & - & 3.76 & 0.16 & 1.03 \\
\hline loadings) & & 2.15 & & 0.11 & & 2.15 & & & \\
\hline $\begin{array}{l}\text { PC2 Med income (factor } \\
\text { loadings) }\end{array}$ & 3,246 & $\begin{array}{c}- \\
3.14\end{array}$ & 2.51 & $\begin{array}{c}- \\
0.24\end{array}$ & 0.96 & $\begin{array}{c}- \\
3.14\end{array}$ & 2.62 & 0.02 & 0.93 \\
\hline
\end{tabular}


As for the year 2016, the attributes of the apartments denote an improved quality and higher price. For example, in comparison to the 2014 dataset, the 2016 apartments are: more expensive, larger, best equipped (i.e. air conditioner, heating and lift, swimming pool and garden), more efficient in energy performance terms, located in better zones (i.e. more central, closer to the seashore, transport stations and highway ramps) and wealthier zones. Why the apartments seem to be improved in all the aforementioned aspects? As it is known, 2014 year was still a moment of real estate crisis in Spain when most of the properties being offered at that time exhibited poor amenities and attributes. Furthermore, better quality properties are normally taken out from the market since their owners can get a better price quotation during the economic recovery period. Conversely, the worst apartments that usually belong to low-income population do not follow such pattern since this population niche exhibits a higher unemployment rate and mortgage evictions. This process is typical in countries such as Spain where the ownership is the dominant housing tenure.

The method used is the hedonic model (Rosen, 1974). This method assumes that the price paid for the asset from housing buyers is equal to the total utility they extract from it, being this a composite utility coming from the marginal attribute of the dwelling (e.g. area, quality, location, etc.). It is possible to calculate such marginal utility expressed in monetary terms by a regression model. In this paper, the used model used departs from the following function:

$$
\ln (P)=c+\sum_{i=1}^{n} X_{i} A_{i}+X E+\sum_{i=1}^{n} X_{i} B_{i}+\sum_{i=1}^{n} X_{i} L_{i}+\sum_{i=1}^{n} X_{i} S_{i}+\varepsilon
$$

\section{Where}

$P$ is the asking selling price

$A$ is a set of apartment's $i$ architectonic attributes

$X \mathrm{~s}$ are the coefficients for each of the variables expressed as price semi-elasticities (see below)

$E$ is the apartment's energy rank derived from EPC

$B$ is a set of $i$ facilities and amenities of the buildings where the apartment is located

$L$ is a set of locative $i$ attributes regarding transport and environmental quality of the site where the apartment is located $S$ is a set of socioeconomic attributes of the population living around the apartment $\varepsilon$ is the error term

The functional form used is log-linear since it accomplishes with the basic statistics premises for ordinary least squares (OLS) calibrating process: normality of residuals, homoscedasticity, and multi-collinearity absence. Also, it allows to identify the marginal price of attributes expressed in semi-elasticities, it is to say the price increase in percentage terms associated with the unitary increase of the independent variables.

Due to the interest of this paper is to analyze whether the EPC rank marginal price has remained stable along the time, the procedure applied is that proposed by Sander (1992). It consists of analyzing the increase of prices using a pooled sample (i.e. 2014 and 2016 datasets together), controlling for the year to which each case belongs to and the eventual increase of EPC rank marginal price. As a result, equation (1) is transformed into:

$$
\ln (P)=c+\sum_{i=1}^{n} X_{i} A_{i}+X E+\sum_{i=1}^{n} X_{i} B_{i}+\sum_{i=1}^{n} X_{i} L_{i}+\sum_{i=1}^{n} X_{i} S_{i}+B 2016+X E_{2016}+\varepsilon
$$

Where

2016 is a year dummy variable equal to one if the dwelling comes from the 2016 dataset and zero otherwise $E 2016$ is an interaction term between the $E$ energy rank and the dummy variable 2016. In absence of an increase of the impact of energy rankings on housing prices the associated coefficient of this variable will appear as statistically insignificant.

Finally, it has been found that apartments' prices do not only respond to their locative and architectonic attributes, but also to the price of neighboring apartments (i.e. spatial dependence). According to the Moran's I the spatial autocorrelation of error from the OLS model of equation 2 is 0.22 (sig=0.00). The omission of this issue might lead to biased coefficients. For this reason, according to Ord (1975) the best way to correct the spatial dependence issue is looking at the largest and most significant value of the following Lagrange Multiplier Diagnostics: Lagrange Multiplier (lag); Robust Lagrange Multiplier (lag), Lagrange Multiplier (error), Robust Lagrange Multiplier (error) and Langrage Multiplier (SARMA). In our case, the Lagrange Multiplier (error) approach resulted in the largest value equivalent to $981.38($ sig=0.00)). As a result $(2)$ is transformed into the spatial error model used in this paper: 
$\ln (P)=c+\sum_{i=1}^{n} X_{i} A_{i}+X E+\sum_{i=1}^{n} X_{i} B_{i}+\sum_{i=1}^{n} X_{i} L_{i}+\sum_{i=1}^{n} X_{i} S_{i}+B 2016+X E_{2016}+\varepsilon$ (3)
Being $\varepsilon=\lambda W \varepsilon+u$

Where $I$ is the autoregressive coefficient, $W$ is the spatial matrix (in this case calculated following rook contiguity criteria) and $u$ is the uncorrected error term.

Table 3 contains the results for the best model coming from the calibration of equation (3) in GeoDa. In such a table, it is possible to see that the average increase in terms of asking prices has been $4.1 \%$ for the period studied ( $1^{\text {st }}$ Nov 2014 $1^{\text {st }}$ April 2016). The results organized by conceptual dimensions are as follow:

Structural architectonic characteristic of apartments and buildings. In the first place appears the area of the apartment, the negative sign of the square of this variable suggest the presence of diminishing returns. In this dimension the next variable to enter is the number of bathrooms: for each additional bathroom apartment's price increases $9.8 \%$; the presence of lift is also an important factor its average impact is $8.9 \%$ of housing prices. Other structural attributes exhibit a modest influence on prices. For example, the presence of an air conditioner contributes to an average increase of $7.4 \%$ of asking prices, while the central heating system implies an increase of $4.1 \%$ of prices. It is important to note that the presence of a swimming pool in the buildings shows the highest contribution to housing prices (18.6\%). Following Olaussen et al. (2017) the age has been introduced following an inverse function. Such approach allows considering a larger impact of this attribute in the case of new and recently completed apartments, while in the case of old and very old ones the difference is smoother.

Energy efficiency attributes. There is also a positive increment of prices coming for efficient energy ranking as previous research has pointed out. In relation to rank $G$ (the comparison base) energy class " $A$ " increases prices in $8.6 \%$ for both years, the remainder of the classes for the base year fails to be statistically significant. This finding is plenty compatible with the results reported by Marmolejo (2016) since it confirms a scarce impact of energy efficiency on residential prices at the basis year. However, the interaction variables (i.e. 2016 x EPC ranks) suggest that the importance of energy ranks on price formation has clearly increased, as further discussed.

Locative attributes. The most relevant variables, regarding characteristics of transport, centrality as well as facilities and amenities, are the average gross area floor ratio (i.e. built up density), followed by the centrality index and commuting time. The positive sign of the first two indicators confirms that prices peak in central zones; however, the positive sign of the third indicator requires a special interpretation. The metropolitan area of Barcelona is a polycentric system gathering together, beyond the central conurbation, mature subcentres that were formerly independent centers, small towns, and rural villages. In these latter settlements, housing price is cheaper than in centralities, at the same time commuting time is smaller than in the very center (due they are largely self-contained in mobility terms). For this reason, commuting time is proxying for the location in the central conurbation, and consequently appears positively correlated with prices. The proximity to the seashore has a large impact on prices. It is important to note that housing price shows an average increase of $13.1 \%$ if the apartments are located within 200 meters from the waterfront.

Socioeconomic attributes. The synthetic indicators suggest that prices are enormously correlated with the place of residence of higher-educated people working in the best job positions (PC1-High Income). To a lesser extent, such positive correlation is also present for the case of medium income classes (PC2- Med Income).

Figure 1 portrays the evolution of the impact of energy efficiency classes on prices. According to the multiplicativeinteraction terms built from the energy rank and the Year 2016, the impact of more efficient ranks has increased in a monotonic coherent fashion: $10.7,10.6$ and $10.5 \%$ for ranks " $B$ ", " $C$ ", and " $D$ ", respectively. As a matter of fact, the increment of the impact of ranked " $A$ " apartments is also positive but fails to meet the $90 \%$ confidence criteria. Overall, these results suggest that in a short period energy efficiency in Barcelona has gained importance in terms of residential prices. Green premiums and brown discounts have started to converge to what is observed in other European countries, opening new opportunities for the development of efficient housing and the retrofit of the existing stock as next discussed. 
Table 3. Results of the pooled 2014 - 2016 sample model. Source: Own elaboration.

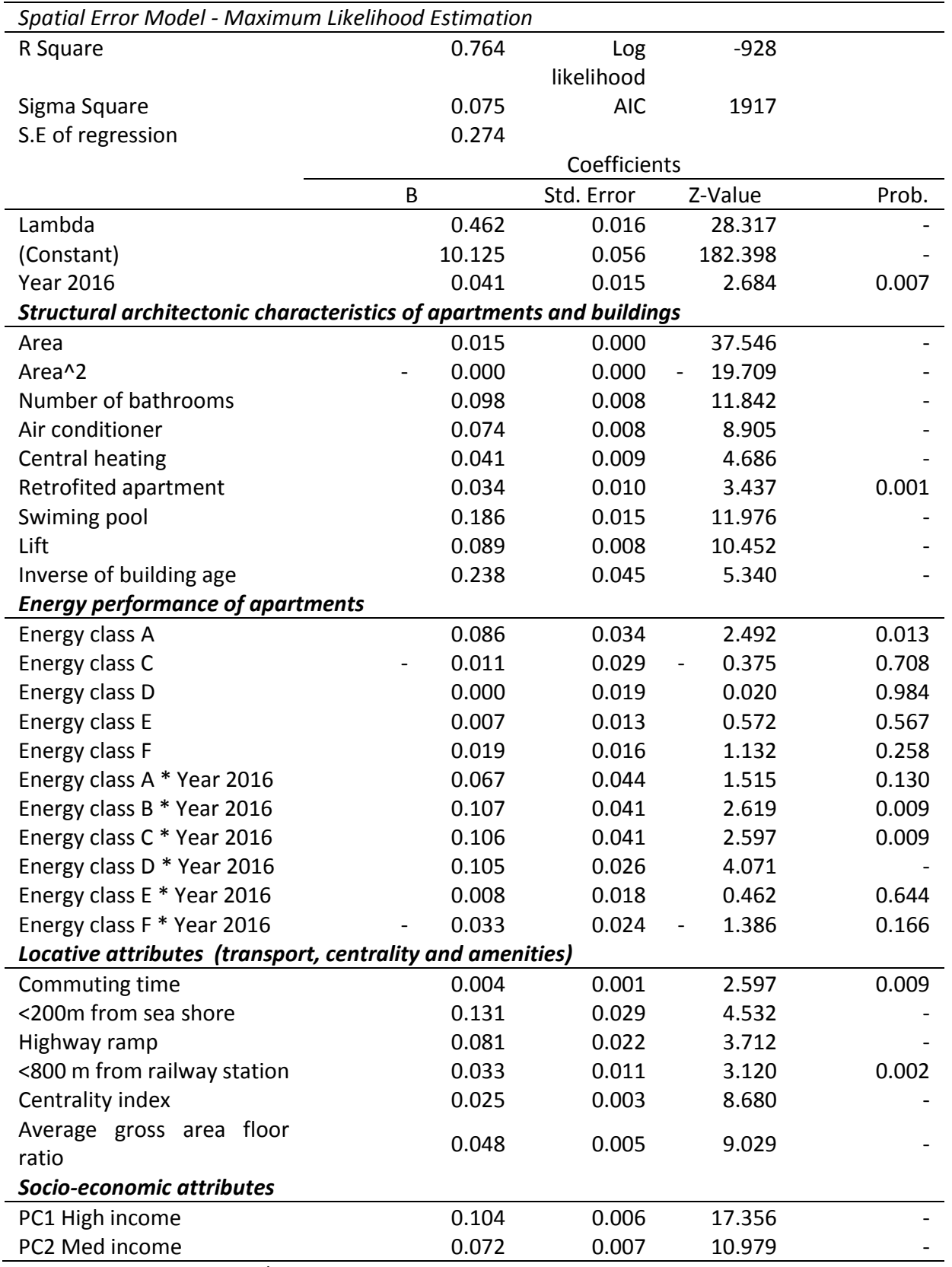

Note: independent variables/covariates are introduced using the stepwise method.

Figure 1. Evolution of the energy rank impact on residential prices 2014-2016. Source: Own elaboration

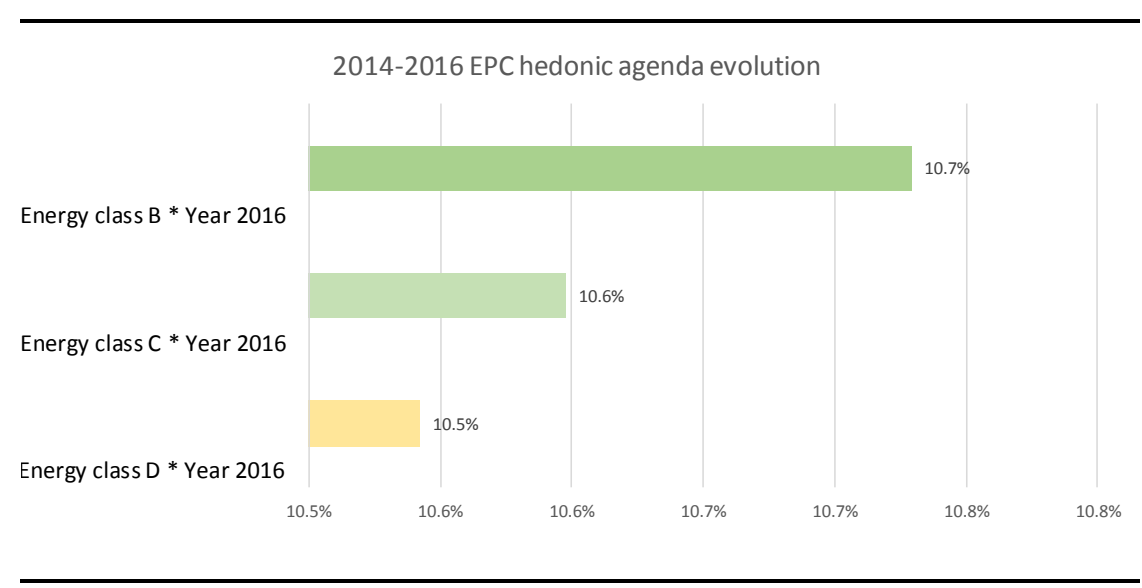


Departing from listing prices for 2014 and 2016 in this research, a set of spatial pooled regression models has been performed. Such analyses suggest that, as the time evolves, the market premium for energy efficiency (i.e. semielasticity or the percent price increase for each EPC energy rank) has increased in the main real estate market of the second largest urban agglomeration of Spain. In absolute terms (i.e. Euros) such market premium is still more important since market prices have increased $4.6 \%$ in the studied period due to the change of economic cycle that has marked the end of the real estate crisis in Spain. According to Garcia Navarro et al. (2014), the 2016 market premium for efficient homes found in this paper is able to overcome the increased construction costs associated with better energy-efficiency materials and building procedures. That is, matching the premia that developers can get from efficient buildings with the production cost is a critical issue in achieving the outcomes pursue by the Energy Performance of Building Directive. Our analyses suggest that in general, the more efficient ranks do exhibit an increased impact of housing prices. Such increment ranges $10.7 \%$ to $10.5 \%$ for the " $\mathrm{B}$ " to " $\mathrm{D}$ " ranks respectively. Rank " $\mathrm{A}$ ", also shows a positive increase but fails to meet the significance criteria.

Whether the rise of energy premiums for efficient homes in Spain is a product of the natural implementation of the EPC policy is an open question. Nonetheless, in this period of time, the significant increments in the price of energy have occurred in the country. This inflationist episode might have influenced households to penalize inefficient homes markedly. In any case, the increase of energy premiums in the Spanish residential market is a clear convergence to the European agenda of EPC hedonic prices.

Our study is limited in nature since in absence of transaction prices it has been powered by listing prices. Since the negotiation ratio (i.e. selling prices/listing prices) might be different across urban locations or housing qualities, there is a certain possibility that the actual impact of EPC ranking on prices may differ from that reported in our analysis. Also, it is necessary to undercover whether the evolution of the impact is the same across different submarkets since previous research has found divergent impacts.

Acknowledgments

This paper has been produced in the framework of EnerVALOR project (SPAIN MINECO FEDER BIA2015-63606-R) leaded by the first author, as well as in the doctoral dissertation of the second author. The authors wish to thank Habitaclia for allowing to use both of the datasets analyzed in this paper. The authors tanks to the remainder of the project researchers for their suggestions and help in producing this piece.

References

Bio Intelligence Service; Mudgal, S.; Lyons, L., \& Cochen, F. (2013). Energy performance certificates in buildings and their Impact on transaction prices and rents in selected EU Countries. Bio Intelligence Service Working Paper. April 2013. Available online: https://ec.europa.eu/energy/sites/ener/files/documents/20130619-energy_performance_certificates_in_buildings.pdf (accessed on 9 June 2018).

Brounen, D., \& Kok, N. (2011). On the economics of energy labels in the housing market. Journal of Environmental Economics and Management, 62(2), 166-179. doi: https://doi.org/10.1016/j.jeem.2010.11.006

Cerin, P., Hassel, L. G., \& Semenova, N. (2014). Energy performance and housing prices. Sustainable Development, 22(6), 404-419. doi: https://doi.org/10.1002/sd.1566

Davis, P. T., McCord, J. A., McCord, M., \& Haran, M. (2015). Modelling the effect of energy performance certificate rating on property value in the Belfast housing market. International Journal of Housing Markets and Analysis, 8(3), 292-317. doi: https://doi.org/10.1108/IJHMA-09-20140035

De Ayala, A., Galarraga, I., \& Spadaro, J. V. (2016). The price of energy efficiency in the Spanish housing market. Energy Policy, 94, 16-24. doi: https://doi.org/10.1016/j.enpol.2016.03.032

Encinas, F., Marmolejo-Duarte, C., de la Flor, F. S., \& Aguirre, C. (2018). Does energy efficiency matter to real estate-consumers? Survey evidence on willingness to pay from a cost-optimal analysis in the context of a developing country. Energy for Sustainable Development, 45, 110-123. doi: https://doi.org/10.1016/j.esd.2018.05.008

Fregonara, E., Rolando, D., \& Semeraro, P. (2017). Energy Performance Certificates in the Turin real estate market. Journal of European Real Estate Research, 10(2), 149-169. doi: https://doi.org/10.1108/JERER-05-2016-0022

Garcia Navarro, J., González Díaz, M. J., \& Valdivieso, M. (2014). Estudio PRECOST\&E: Evaluación de los costes constructivos y consumos energéticos derivados de la calificación energética en un edificio de viviendas situado en Madrid. Informes de la Construcción, 66(535), 1-10. doi: https://doi.org/10.3989/ic.13.052 
García-Hooghuis, A., \& Neila, F. (2013). Modelos de transposición de las Directivas 2002/91/CE y 2010/31/UE “Energy Performance Building Directive” en los Estados miembros de la UE. Consecuencias e implicaciones. Informes de la Construcción, 65(531), 289-300. doi: https://doi.org/10.3989/ic.12.017

Hyland, M., Lyons, R. C., \& Lyons, S. (2013). The value of domestic building energy efficiency-evidence from Ireland. Energy economics, $40,943-952$. doi: https://doi.org/10.1016/j.eneco.2013.07.020

Marmolejo-Duarte, C., \& González, C. (2009). Does noise have a stationary impact on residential values? Journal of European Real Estate Research, 2(3), 259-279. doi: https://doi.org/10.1108/17539260910999992

Marmolejo-Duarte, C., \& Cerda, J. (2012). La densidad-tiempo: otra perspectiva de análisis de la estructura metropolitana. Scripta Nova: Revista Electrónica de Geografía y Ciencias Sociales, 16. doi: http://dx.doi.org/10.1344/sn2012.16.14762

Marmolejo-Duarte, C., \& Cerda, J. (2017). El comportamiento espacio-temporal de la población como instrumento de análisis de la estructura urbana: el caso de la Barcelona metropolitana. Cuadernos Geográficos, 56(2),111-133. Available on: http://revistaseug.ugr.es/index.php/cuadgeo/article/view/4704/5616 (accessed on 13 May 2018).

Marmolejo-Duarte, C.; Echavarria, C.; Biere, R. (2016) The value of centrality: an analysis for the Metropolitan Barcelona, ACE: Architecture, City and Environment, 11 (32): 95-112 http://dx.doi.org/10.5821/ace.11.32.4834

Marmolejo-Duarte, C. (2016). La incidencia de la calificación energética sobre los valores residenciales: un análisis para el mercado plurifamiliar en Barcelona. Informes de la Construcción, 68(543), 156. doi: https://doi.org/10.3989/ic.16.053

Marmolejo-Duarte, C., \& Chen, A. (2019a). The Uneven Price Impact of Energy Efficiency Ratings on Housing Segments and Implications for Public Policy and Private Markets. Sustainability, 11(2), 372. doi: https://doi.org/10.3390/su11020372

Marmolejo-Duate, C., \& Chen, A. (2019b). The impact of EPC rankings on the Spanish residential market:an analysis for Barcelona, Valence and Alicante, Ciudad y Territorio, Estudios Territoriales, (LI), 199: 101-118

Marmolejo-Duarte, C., \& Bravi, M. (2017). Does the Energy Label (EL) Matter in the Residential Market? A Stated Preference Analysis in Barcelona. Buildings, 7(2), 53. doi: https://doi.org/10.3390/buildings7020053

Murphy, L. (2014). The influence of the energy performance certificate: The Dutch case. Energy Policy, 67, 664-672. doi: https://doi.org/10.1016/j.enpol.2013.11.054

Olaussen, J.O., Oust, A., \& Solstad, J.T. (2017). Energy Performance Certificates-Informing the Informed or the Indifferent? Energy Policy 111, 246254. doi: http://dx.doi.org/10.1016/j.enpol.2017.09.029

Ord, J.K. (1975) Estimation methods for models of spatial interaction. Journal of the American Statistical Association, 70, 120-126. doi: https://doi.org/10.1080/01621459.1975.10480272

Parkinson, A., De Jong, R., Cooke, A., \& Guthrie, P. (2013). Energy Performance Certification as a Signal of Workplace Quality. Energy Policy, 62, 14931505. doi: http://dx.doi.org/10.1016/j.enpol.2013.07.043

Pascuas, R.P., Paoletti, G., \& Lollini, R. (2017). Impact and Reliability of EPCs in The Real Estate Market. Energy Procedia, 140, 102-114. doi: http://dx.doi.org/10.1016/j.egypro.2017.11.127

Pena Trapero, J. B. \& Pena Trapero, X. (1977). Problemas de la medición del bienestar y conceptos afines: una aplicación al caso español. Madrid: España: Instituto Nacional de Estadística.

Rosen, S. (1974). Hedonic prices and implicit markets: product differentiation in pure competition. Journal of political economy, 82(1), 34-55. doi: https://doi.org/10.1086/260169

Sander, W. (1992). The effect of women's schooling on fertility. Economics Letters, 40(2), 229-233. doi: https://doi.org/10.1016/0165-1765(92)90229$r$

Zarzosa-Espina, P. (2009). Estimación de la pobreza en las comunidades autónomas españolas, mediante la distancia DP2 de Pena. Estudios de economía aplicada, 27(2), 397-416. Available on: https://dialnet.unirioja.es/servlet/articulo?codigo=3056904 (accessed on 10 January 2019) 